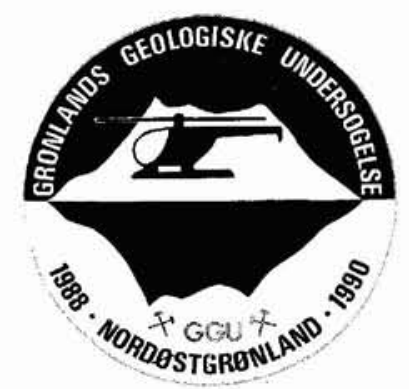

\title{
Surge of Storstrømmen, a large outlet glacier from the Inland Ice of North-East Greenland
}

\author{
Niels Reeh, Carl Egede Bøggild \\ and Hans Oerter
}

\begin{abstract}
During field work in 1989 it was noted that the front of Storstrømmen glacier, North-East Greenland, had advanced by more than $10 \mathrm{~km}$ as compared to its position in 1978. Inspection of satellite images shows that the advance took place in the period from 1978 to 1984. Scattered observations of frontal positions back to 1913 indicate a general retreat until 1978. During the advance after 1978, the ice discharge in the frontal region of Storstrømmen was as much as $10.8 \mathrm{~km}^{3}$ per year, which is about half the discharge from Jakobshavn Isbræ, West Greenland, the most productive calving glacier in Greenland. Observed surface-elevation and surface-velocity changes during a period overlapping that of the large frontal advance show all the characteristics associated with a surge.
\end{abstract}

N. R., Dansk Polarcenter/Geological Survey of Greenland, Øster Voldgade 10, DK-1350 Copenhagen $K$, Denmark.

C. E. B. \& H. O., Alfred Wegener Institut for Polar and Marine Research, D-2850 Bremerhaven, Germany.

'Present address: Geological Survey of Greenland, Øster Voldgade 10, DK-1350 Copenhagen K, Denmark.

Reconnaissance flights over the frontal region of Storstrømmen during 1989 revealed that the calving front had advanced by more than $10 \mathrm{~km}$ since the last aerial photograph coverage in 1978.

The aim of this paper is to discuss fluctuations of the front of Storstrømmen during the past 80 years, with special emphasis on the period of the rapid frontal advance. Prior to the advance in 1978, frontal positions were located using aerial photographs and expedition reports going back to the beginning of the century. Frontal positions since 1978 are provided by analysis of satellite images. Calculated balance-velocity distributions before and after the advance have been compared with observed surface velocities. This comparison reveals large changes of the dynamics of Storstrømmen in a period encompassing the time of the rapid frontal advance which shows many characteristics associated with a surge. Finally, the stability of the floating glacier tongue and the marine section of the glacier is discussed.

Similar large frontal advances have been reported for a few local glaciers in North and East Greenland, e.g. for a glacier in Victoria Fjord $\left(82^{\circ} \mathrm{N}, 45^{\circ} \mathrm{W}\right)$ by Higgins \& Weidick (1988), and for glaciers in the Scoresby Sund area $500 \mathrm{~km}$ further to the south (Olesen \& Reeh, 1969; Rutishauser, 1971). However, this is the first report of recent fluctuations of the Inland Ice margin in North-East Greenland.

Weidick (1988) discussed a number of documented surging or pulsating outlet glaciers in other parts of Greenland, for example Equalorutsit Kitdlit Sermia in South Greenland $\left(61^{\circ} \mathrm{N}, 45^{\circ} \mathrm{W}\right)$ which showed a sudden advance in the beginning of the 1940s (Weidick, 1984). Another example is Harald Moltke Bræ in North-West Greenland $\left(76^{\circ} 35^{\prime} \mathrm{N}, 67^{\circ} 55^{\prime} \mathrm{W}\right)$ which calves into Wolstenholme Fjord, and is reported to have undergone a change in velocity from $30 \mathrm{~m} / \mathrm{yr}$ to $1000 \mathrm{~m} / \mathrm{yr}$ between 1915 and 1965 (Mock, 1966).

As mentioned above, the calving front of Storstrømmen advanced more than $10 \mathrm{~km}$ between 1978 and 1984. During this period, c. $11 \mathrm{~km}^{3} / \mathrm{yr}$ of ice was extruded into Borgfjorden from Storstrømmen (Fig. 1). This is about half the calving flux from Greenlands most productive calving glacier, Jakobshavn Isbræ (e.g. Echelmeyer et al., 1991), and three times the ice calving fluxes from all the major outlet glaciers from the Inland Ice in North Greenland (Higgins, 1991). During the advance, the average velocity in the frontal region of Storstrømmen must have reached at least $2 \mathrm{~km} / \mathrm{yr}$.

In July-August 1989 and 1990 a glaciological programme was carried out on the margin of Storstrømmen 


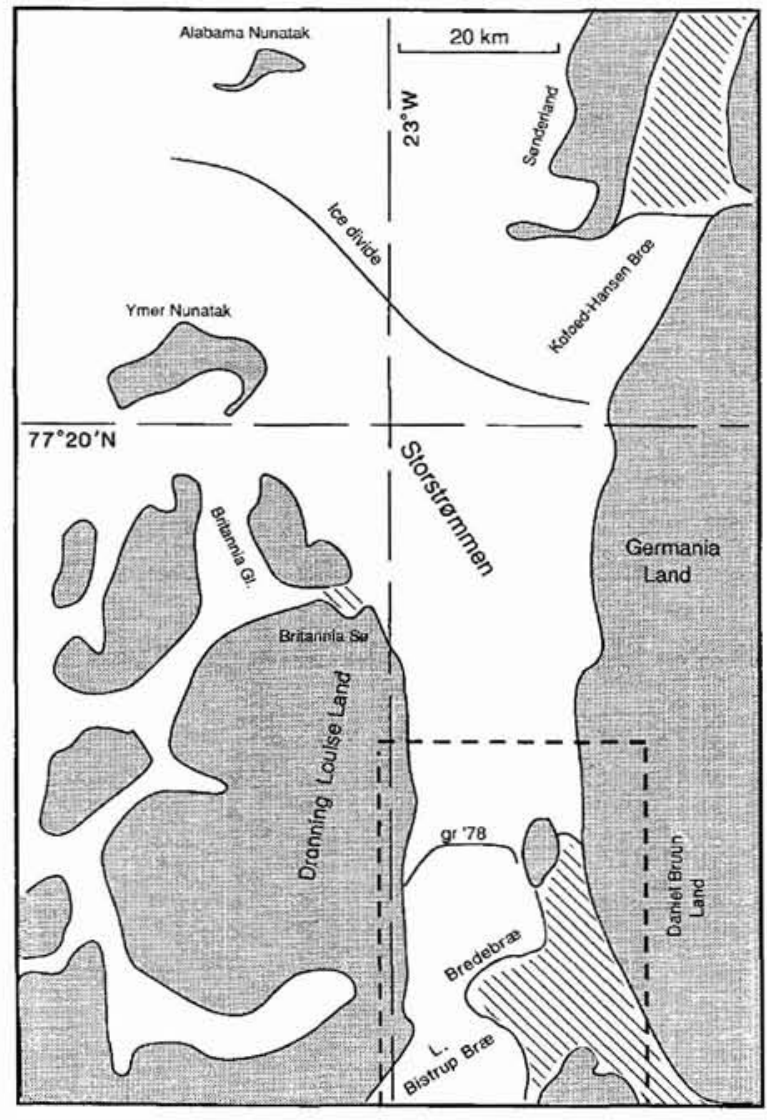

Fig. 1. Map of Storstrømmen. The approximate location of the grounding line shown by ' $\mathrm{gr}$ ' 78 ', has been determined from the surface contour map based on aerial photographs from 1978 (GGU, 1990, 1992) and airborne radio echo soundings also from 1978 (Overgaard, 1984); see Figure 4. Dashed line shows frame of Figures 2 and 3.

glacier, North-East Greenland $\left(77^{\circ} \mathrm{N}, 22^{\circ} \mathrm{W}\right)$ by the Alfred Wegener Institute for Polar and Marine Research, Bremerhaven. The glaciological programme shared logistic support with an expedition to North-East Greenland organised by the Geological Survey of Greenland.

\section{The Storstrømmen - Kofoed-Hansen Bræ glacier complex}

Several outlet glaciers drain the Greenland Inland Ice north of Dronning Louise Land around $77^{\circ} 30^{\prime} \mathrm{N}$. The most important are Kofoed-Hansen Bræ and Storstrømmen (Fig. 1) which drain through the $30 \mathrm{~km}$ gap between Ymer Nunatak and Alabama Nunatak at an elevation of about $1050 \mathrm{~m}$, which roughly coincides with the altitude of the equilibrium line. After an icefall at $800 \mathrm{~m}$ above sea level (a.s.l.), the flow direction of Storstrømmen and Kofoed-Hansen Bræ changes from an easterly to a more south-easterly direction. A second icefall is found around $300 \mathrm{~m}$ a.s.l. A NW-SE trending ice divide, which terminates in Germania Land at around $300 \mathrm{~m}$ elevation, separates ice flowing north-east (Kofoed-Hansen Bræ) from ice flowing south (Storstrømmen); the latter follows a southerly direction for another $50 \mathrm{~km}$ between Dronning Louise Land and Germania Land before terminating in Borgfjorden. At $100 \mathrm{~m}$ altitude, the flow of Storstrømmen is divided by a small semi-nunatak, into two calving fronts: the $12 \mathrm{~km}$ wide Bredebræ front and a $4 \mathrm{~km}$ wide front, for convenience referred to as 'Northern Front'. Near Bredebræ, Storstrømmen merges with L. Bistrup Bræ, a large glacier which flows south of Dronning Louise Land. To judge from the flow-pattern apparent at the surface of the glaciers near their junction line, L. Bistrup Bræ appears to have remained essentially stationary, so that the advance of the calving front after 1978 must be ascribed to Storstrømmen.

\section{Frontal variations 1913-1978}

Figure 2 shows marginal positions before the initiation of the frontal advance in 1978. The positions of Bredebræ and 'Northern Front' were first observed during the 1906-08 Danmark Ekspedition. However, the frontal positions shown on the map published after the expedition

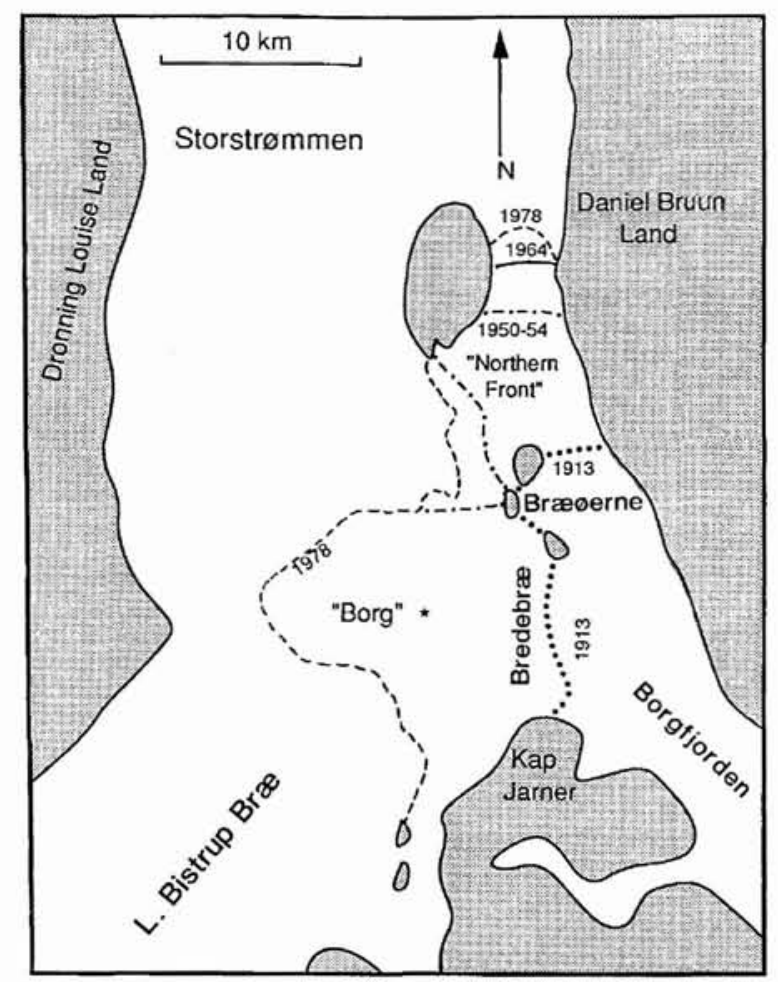

Fig. 2. Frontal positions af Storstrømmen from 1913 to 1978 (see lower right corner in Fig. 1 for location). 
by Koch \& Wegener (1911) are rather schematic, and probably not accurate enough to allow conclusions about later fluctuations. In 1912 J. P. Koch and A. L. Wegener returned to North-East Greenland. They spent the winter of 1912-13 at their station Borg erected on Storstrømmen near Bredebræ before their crossing of the Inland Ice in 1913. During their stay, a detailed survey of the front was made (Koch \& Wegener, 1930). The map compiled from the observations in 1912-13 shows the east-facing Bredebræ front to pass from Kap Jarner northwards to Braøerne, and the south-facing 'Northern Front' to be located between Bræøerne and Daniel Bruun Land. The height of the calving front approximately half-way between Kap Jarner and Bræøerne was determined to be 32 $\mathrm{m}$ above sea level. At the wintering station Borg (Fig. 2) some $4 \mathrm{~km}$ upstream from the calving front, the surface elevation was determined to be $64 \mathrm{~m}$ a.s.l., and the ice movement to be $1.7 \mathrm{~km} / \mathrm{yr}$.

Maps based on aerial photographs taken in 1950 for the British North Greenland Expedition (Hamilton et al.,1956) show calving front positions similar to those obtained from oblique aerial photographs taken a few years later in 1954. Between 1913 and 1950 the 'Northern Front' had retreated $8 \mathrm{~km}$ whereas the Bredebræ front had retreated up to $15 \mathrm{~km}$, causing an embayment to open up between Storstrømmen and L. Bistrup Bræ. The junc-

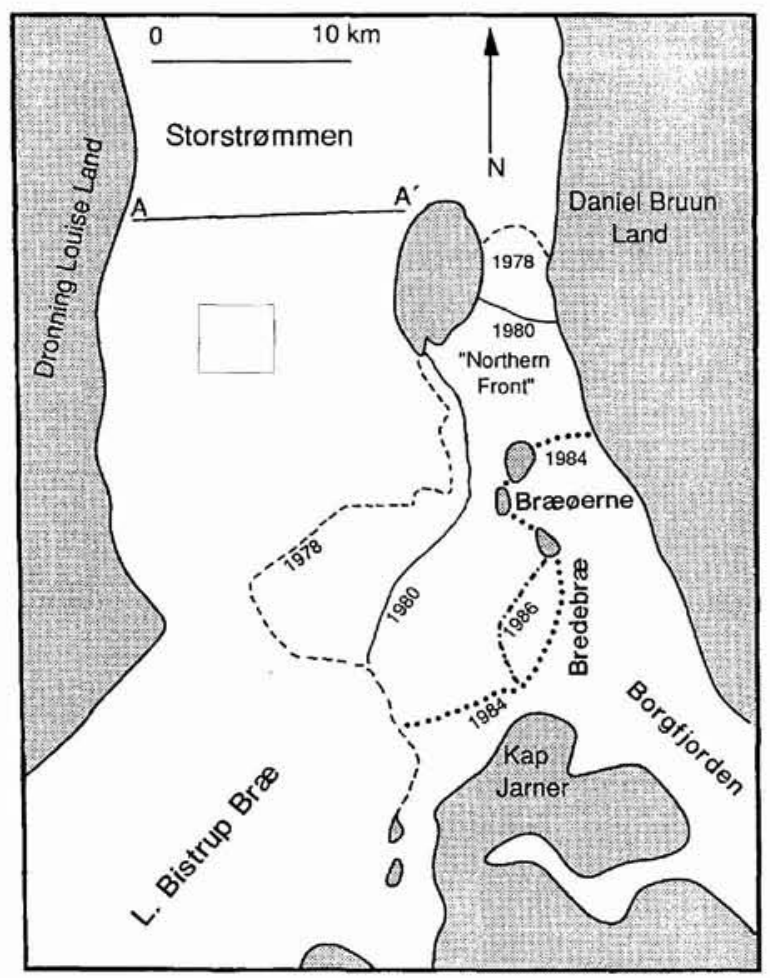

Fig. 3. Frontal positions of Storstrømmen from 1978 to 1986 (see lower right corner in Fig. 1 for location).

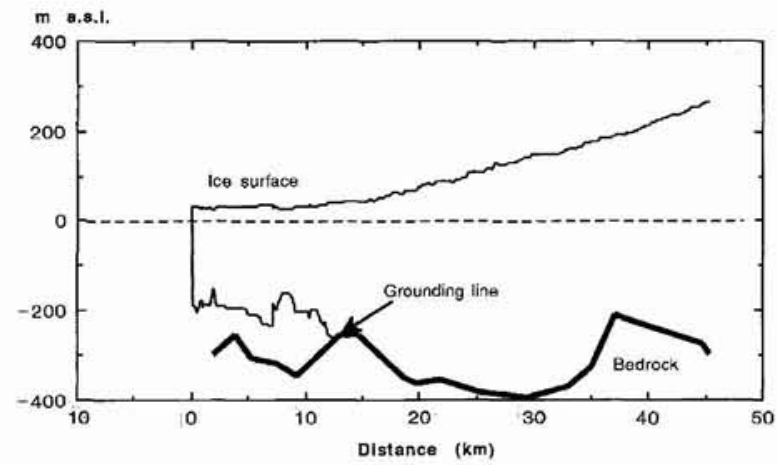

Fig. 4. Longitudinal section along the central flowline leading to front of Bredebre. The ice surface is determined from the surface contour map based on aerial photographs from 1978 (GGU, 1990; 1992). Heavy line marks bottom topography as determined by airborne radio echo soundings in 1978 (Overgaard, 1984). The thickness of the floating part of the glacier is determined from the surface altitude, assuming free floating conditions.

tion between the two glaciers was thus reduced to a $4 \mathrm{~km}$ wide confluence zone.

The occurrence of large tabular icebergs and tidal cracks along the 'Northern Front' on 1954 photographs can be taken as an indication of a floating front (Mock, 1966). However, on aerial photographs taken in 1964 and 1978 very few icebergs can be seen in front of 'Northern Front', and tidal cracks are not visible behind the front. This probably means that the 'Northern Front' retreated to the grounding line during the recession from 1954 to 1964. As opposed to 'Northern Front', the Bredebre front was apparently afloat even in the retreat stage between 1950 and 1978. That Storstrømmen was afloat in 1978 over a $10-15$ kilometre distance behind the Bredebra front is illustrated in Figure 4. The fact that the position of the Bredebre front was virtually unchanged during the period 1950-1978 suggests that the 1978 situation is representative for the entire period.

\section{Frontal variations 1978-1991}

Between 1978 and 1980 a major advance occurred along both the 'Northern Front' and the Bredebræ front (Fig. 3). The advance of the 'Northern Front' was about 4 $\mathrm{km}$ and covered an area of $15 \mathrm{~km}^{2}$. The advance of Bredebræ first filled up the previously mentioned embayment, and was subsequently followed by a frontal advance of $1-2 \mathrm{~km}$. The area covered by the advance of Bredebræ was $75 \mathrm{~km}^{2}$, of which the former embayment constitutes approximately $50 \mathrm{~km}^{2}$.

Between 1980 and 1984 Storstrømmen made further advances along both fronts. The 'Northern Front' advanced some $8 \mathrm{~km}$ into Borgfjorden reaching the 1913 


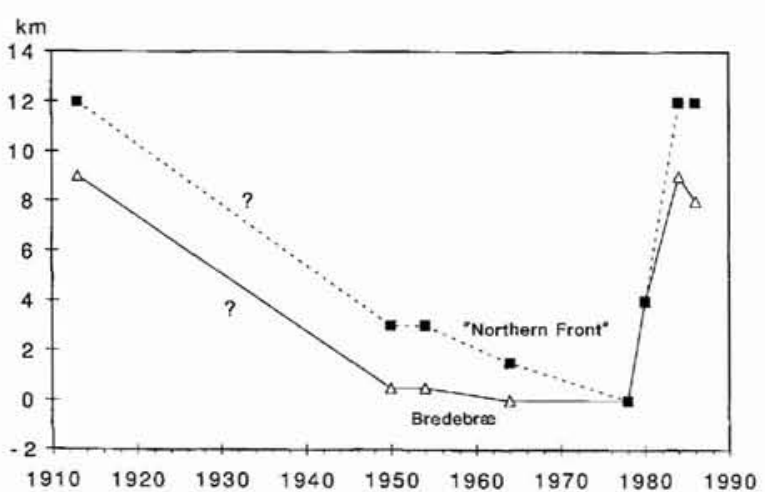

Fig. 5. Frontal variations of Storstrømmen since 1912-13. The front position in 1978 is used as datum.

front position at Bræøerne, thus adding an area of about $48 \mathrm{~km}^{2}$ to the glacier. As far as Bredebræ is concerned, flow-lines apparent on LANDSAT satellite images can be traced some $8 \mathrm{~km}$ further out into Borgfjorden than the 1980 front position, so that the 1984-position of the Bredebræ front was almost identical to the 1913 position.

Since 1984 the frontal positions have remained static, although some disintegration of the Bredebræ front began in 1986: satellite images from 1986 reveal a fracture zone had opened up just south of Bræøerne releasing a $20 \mathrm{~km}^{2}$ segment from the front. Since 1986 no major changes have occurred in the position of the fronts, although large crevasses have been formed in the frontal region of the glacier.

The frontal variations are further illustrated in Figure 5 which shows frontal positions along the central flow lines leading to 'Northern Front' and Bredebræ respectively, using the positions in 1978 as datum. Although the general pattern of variation is the same for the two fronts, there are important differences, particularly in the period 1950-1978. Whereas in this period the Bredebræ front was virtually unchanged at its most retreated position, 'Northern Front' experienced a gradual retreat, and did not reach its most retreated position until sometime between 1964 and 1978. This difference in behaviour will be further commented on in the discussion.

Based on observations by J. P. Koch and A. L. Wegener (Koch, 1913; Koch \& Wegener, 1930) and photogrammetric altitude measurements (GGU, 1992), the mean altitude of the calving front is estimated to be approximately $30 \mathrm{~m}$ a.s.l. Assuming the front to be afloat, this gives a minimum average thickness of the floating tongue of $210 \mathrm{~m}$. Based on the area added to the glacier during the advance between 1978 and 1984 and this ice thickness, the cumulative volume of the ice advance is calculated to be as much as $45 \mathrm{~km}^{3}$. Since surface elevations around the equilibrium line were virtually un- changed between 1978 and 1989 (Reeh et al., 1993), the volume added to the frontal part of the glacier during the advance will have to match a mass loss of similar magnitude somewhere in the ablation zone. This mass loss corresponds to a mean thinning of $15 \mathrm{~m}$ over the whole ablation zone. However, a discrepancy of up to $80 \mathrm{~m}$ between surface elevations determined by Doppler satellite measurements in 1989 and 1990, and surface elevations determined photogrammetrically by means of the 1978 aerial photographs shows that the thinning is nonuniform, and that the mass loss is concentrated around $300 \mathrm{~m}$ altitude (Reeh et al., 1993).

\section{Surface velocity observations}

Surface velocities have been measured by means of several methods.

(1) Near the ice margin in Germania Land, theodolite surveying from land based points was used for determining stake displacements during a 13 month period from July 1989 to August 1990. Displacements are accurate to within $10 \mathrm{~cm}$.

(2) Repeated GPS positioning was undertaken in 1990 of stakes between 2.5 and $10 \mathrm{~km}$ from the ice margin in Germania Land. At two points, where a comparison between elevations determined by theodolite surveying and GPS observations was possible, elevation differences were less than $10 \mathrm{~cm}$, indicating an accuracy of the GPS measurements in the order of $10 \mathrm{~cm}$.

(3) In a transect between $6 \mathrm{~km}$ and $60 \mathrm{~km}$ from the eastern margin of Storstrømmen in Germania Land, velocities were determined by repeated positioning in 1989 and 1990 of eight stakes by means of a JMR-1 Doppler satellite receiver. The observations at each point lasted 2-5 days and the number of accepted satellite passages varied between 12 and 25 , yielding an estimated accuracy of the positions of 1-2 m.

(4) Between 700 and $1000 \mathrm{~m}$ elevation a large number of lakes are found on the ice surface (Reeh et al., 1991). The lakes are located in stationary surface depressions and owe their existence to the flow of the glacier over large bedrock undulations. Due to the predominant katabatic wind blowing in the downglacier direction, a pressure ridge forms at the boundary between open water and lake ice every summer. The pressure ridges are passively transported along by the glacier motion and are eventually deposited on the glacier surface as a series of curved ridges, reflecting the crescent-shaped rim of open lake water formed during the summer period by the persistently blowing katabatic wind. Since the ridges are formed 
annually, surface velocities can be derived from the distance between them (Reeh et al., 1991). Similar observations were used by Echelmeyer et al. (1991) to determine surface velocities in the Jakobshavn Isbræ region of West Greenland.

(5) In the region west of the semi-nunatak dividing Storstrømmen into Bredebræ and 'Northern Front', A. K. Higgins (unpublished data) obtained surface velocities by measuring the displacement of distinct features on the surface visible on aerial photographs taken in 1964 and 1978. Along a transect A-A' (Fig. 3) velocities range from less than $20 \mathrm{~m} / \mathrm{yr}$ near the margins to over $100 \mathrm{~m} / \mathrm{yr}$ in the centre. The slowly moving ice near the margins is separated from the fast moving ice in the central section by two parallel shear bands (Fig. 6).

Table 1 shows measured surface velocities of points near the central flowline of Storstrømmen. The velocities were obtained by the different methods described above. More importantly, they represent average velocities over different time periods and at different locations along the central flow line. The Doppler satellite observations provide surface velocities for the period July 1989 to August 1990. The 'lake ridge' velocities on the other hand, represent the period from approximately 1970 to 1978 , whereas the velocities determined by A. K. Higgins are averages for the period 1964-1978. The 'Doppler' velocities and the 'lake ridge' velocities were measured between 50 and $120 \mathrm{~km}$ behind the calving front in contrast to the 'Higgins' velocities which are measured in the region near the grounding line located about $10-15 \mathrm{~km}$ behind the 1978 position of the Bredebræ calving front (see Fig. 1).

Closer to the calving front, direct velocity observations are not yet available. However, based on the magnitude and duration of the rapid frontal advance between 1978

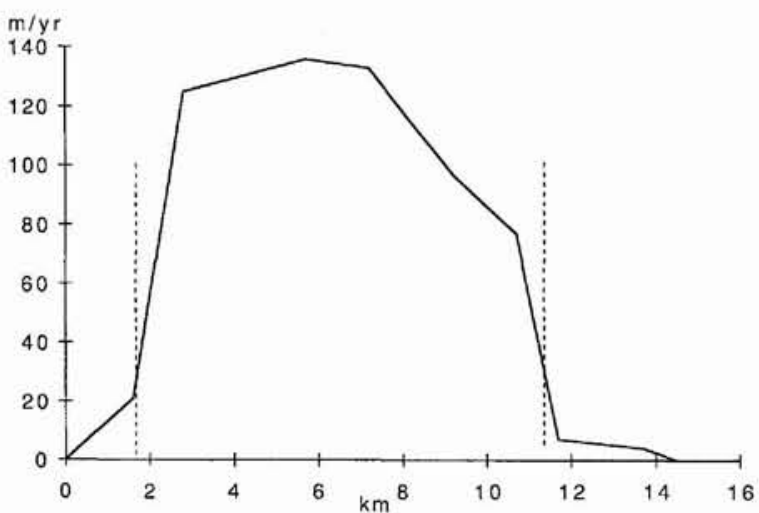

Fig. 6. Velocity distribution of profile A-A'. Dotted lines shows position of shear bands (see Fig. 3 for location).
Table 1. Observed surface velocities

\begin{tabular}{rccl}
\hline $\begin{array}{c}\text { Altitude } \\
\text { m a.s.l. }\end{array}$ & Velocity m/year & Period & Method \\
\hline 1075 & 259 & $1989-1990$ & Doppler \\
860 & 256 & $1970-1978$ & Lake ridges \\
760 & 283 & $1970-1978$ & Lake ridges \\
678 & 249 & $1989-1990$ & Doppler \\
575 & 307 & $1989-1990$ & Doppler \\
430 & 291 & $1989-1990$ & Doppler \\
320 & 272 & $1989-1990$ & Doppler \\
60 & 130 & $1964-1978$ & Acrial photogr. \\
30 & $1500 / 2000$ & $1978-1984$ & Front advance \\
\hline
\end{tabular}

and 1984, a minimum value of the velocity at the front during this period is estimated to be $1.5 \mathrm{~km} / \mathrm{yr}$. A more realistic value of the average frontal velocity in the period $1978-1984$ is probably $2 \mathrm{~km} / \mathrm{yr}$, because the frontal advance was accompanied by significant calving activity filling up Borgfjorden with icebergs.

\section{Temporal velocity variations}

Since the velocities have been observed at different locations along the central flow line, it is in general not possible to use the observations directly to assess temporal variations of the surface velocities. However, by starting at a location where the velocity is known, it is possible to calculate a steady-state (balance) distribution of the surface velocities along the entire central flow line, using the principle of mass conservation (the equation of continuity). Observed velocities at other locations along the flow line can then be compared to the calculated steady state velocities in order to assess possible temporal velocity fluctuations.

In one case, however, a direct comparison between velocities observed in two different periods is possible: average velocities for the period 1989-1990 determined by Doppler satellite observations, and average velocities for the period 1970-1978 based on distances between lake ridges, are located in the same section of the flow line. As will be shown below, these two sets of velocities are in some agreement, indicating no substantial change of the surface velocity in the upper reaches of Storstrømmen between the periods 1970-1978 and 1989-1990. This is consistent with the moderate change of surface elevation between 1978 and 1989-1990 in the same section of the flow line (Reeh et al., 1993), and supports the hypothesis that the upper reaches of Storstrommen were relatively unaffected by the dramatic changes that occurred farther down the glacier between 1978 and 1984.

The continuity equation to be used for calculating 
Table 2. Data used to calculate flux velocities

\begin{tabular}{ccccc}
\hline $\begin{array}{c}\text { Level } \\
\mathrm{m}\end{array}$ & $\begin{array}{c}\text { Width } \\
\mathrm{km}\end{array}$ & $\begin{array}{c}\text { Ice thickness } \\
\mathrm{km}\end{array}$ & $\begin{array}{c}\text { Cross- } \\
\text { sectional area } \\
\mathrm{km}^{2}\end{array}$ & $\begin{array}{c}\text { Surface } \\
\text { area } \\
\mathrm{km}^{2}\end{array}$ \\
\hline 0 & 10 & 0.24 & 2.4 & 100 \\
70 & 15 & 0.4 & 6 & 225 \\
100 & 15 & 0.4 & 6 & 60 \\
200 & 23 & 0.22 & 5.06 & 364 \\
300 & 33 & 0.35 & 11.55 & 435 \\
400 & 25 & 0.45 & 11.25 & 118.75 \\
500 & 22.5 & 0.7 & 15.75 & 281.75 \\
600 & 15 & 0.94 & 14.1 & 137.5 \\
700 & 12.5 & 1 & 12.5 & 142.5 \\
800 & 16 & 1 & 16 & 82.5 \\
900 & 17 & 1 & 17 & 165 \\
1000 & 16 & 1 & 16 & 80 \\
\hline
\end{tabular}

steady-state balance-velocity distributions along the flow line, reads:

$$
V_{i+1}=\left(V_{i} A_{i}+a_{i+1 / 2} S_{i+1 / 2}\right) / A_{i+1}
$$

where $a_{j+1 / 2}$ is the average annual net balance (surface ablation) and $\mathrm{S}_{\mathrm{i}+1 / 2}$ is the area of the glacier surface between the vertical profiles $i$ and $i+1 . V_{i}$ and $A_{i}$ are mean velocity and cross-sectional area of the fast moving, central section of the glacier at position i. Assuming block flow in this section (Fig. 6), the surface velocity can be taken as a good approximation of the mean velocity in the section. In the absence of information about ice thickness variations across the glacier, the average ice thickness in any cross-section is assumed to be equal to the ice thickness observed at the point where the cross-section intersects a longitudinal ice thickness profile obtained by means of airborne radio echo sounding; the latter was undertaken in 1978 by the Electromagnetic Institute, the Technical University of Denmark (Overgaard, 1984).

Balance velocity calculations have been made in steps corresponding to a $100 \mathrm{~m}$ change of altitude along the flow line from sea level up to $1000 \mathrm{~m}$ elevation. Table 2 gives values of the parameters used in the calculations. Surface areas and profile widths are taken from maps at a scale of 1:100 000 drawn by the Geological Survey of Greenland (GGU, 1990, 1992). Ice thicknesses are taken from airborne radio echo measurements.

The net mass balance (surface ablation) used for the calculations is a mean value over the ablation area reconstructed for the period 1961-1990 by means of a degreeday approach (Braithwaite, 1984; Reeh, 1991). The reconstruction is based on mean monthly air temperatures observed at the nearby weather station Danmarkshavn (Bøggild et al., 1994). The degree-day factor and the transfer function for temperatures between Danmarkshavn and Storstrømmen are based on detailed climate and ablation data obtained by field observations at Storstrømmen in 1989 and 1990 (for details, see Bøggild et al., 1994). The reconstructed mass-balance record shows inter-annual variations of the mean specific ablation between $133 \mathrm{~cm}$ of ice/yr and $190 \mathrm{~cm}$ of ice/yr, with a mean of $152 \pm 27 \mathrm{~cm}$ of ice/yr over the area below $1000 \mathrm{~m}$ altitude.

Figure 7 shows four different calculated steady-state surface-velocity distributions along the central flow line of Storstrømmen: (1) Distribution fitted to the velocities determined in the upper part of the ablation area by Doppler satellite observations in the period 1989-1990 and lake ridge distances in the period 1970-1978. (2) Distribution generated by using the average velocity in section A-A' determined by A. K. Higgins for the period 1964-1978 as starting value for the balance velocity calculation. (3) Distribution generated by using a value of $1.5 \mathrm{~km} / \mathrm{yr}$ for the velocity at the 1978-position of the calving front as starting value for the balance velocity calculation; as mentioned above, this value is a minimum estimate of the average frontal velocity in the period of

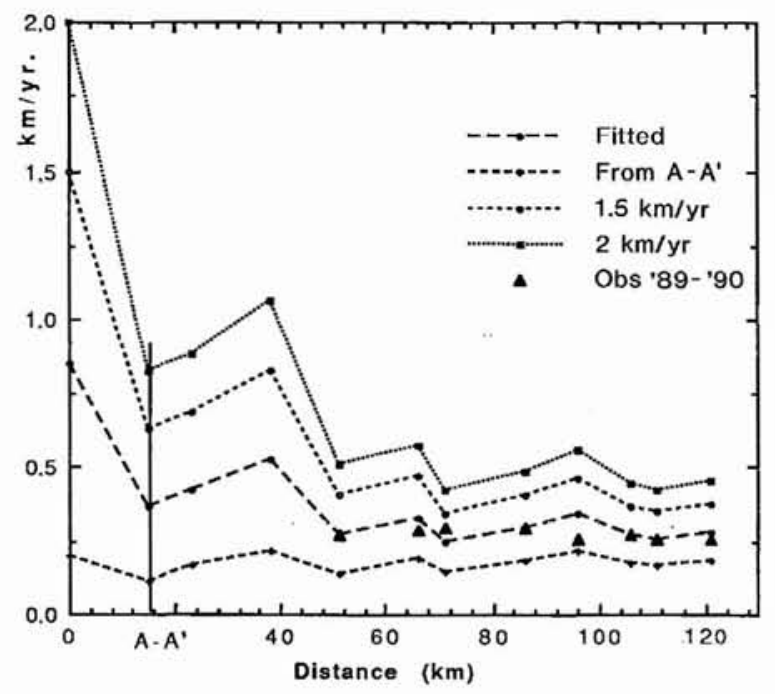

Fig. 7. Calculated balance-velocity distributions along the central flowline of Storstrømmen. Distances are in kilometres behind the 1978-position of the calving front. 'Fitted' denotes the distribution fitted to the velocities determined in the upper part of the ablation area by Doppler satellite observations in the period 1989-1990, and lake ridge distances in the period 19701978. 'From A-A"' denotes the distribution generated by using the average velocity in section A-A' determined by A. K. Higgins for the period 1964-1978 as starting value for the balance velocity calculation. ' $1.5 \mathrm{~km} / \mathrm{yr}$ ' and ' $2 \mathrm{~km} / \mathrm{yr}$ ' denote distributions generated by using values of $1.5 \mathrm{~km} / \mathrm{yr}$ and $2 \mathrm{~km} / \mathrm{yr}$ respectively, for the velocity at the 1978-position of the calving front as starting value for the balance velocity calculation. 
rapid front advance from 1978 to 1984. (4) Distribution using a starting value of $2 \mathrm{~km} / \mathrm{yr}$ for the velocity at the 1978-position of the calving front, which is a more realistic estimate of the average front velocity in the period 1978-1984.

The large differences between the four calculated velocity distributions clearly illustrate that large velocity fluctuations accompanied the observed fluctuations of the glacier front. The relatively good match of the Doppler and lake ridge velocities to the same calculated velocity distribution shows that the upper part of the ablation zone was approximately in balance with the ablation in a period before as well as after the rapid frontal advance. However, this balance velocity distribution is neither consistent with the average velocity determined in section A-A' by Higgins for the period 1964-1978 (i.e before the rapid front advance), nor with the estimate of the frontal velocity during the rapid front advance.

If the average velocity determined by Higgins in section A-A' for the period 1964-1978 is used as starting point for the calculation of a balance-velocity distribution, then the calculated upstream balance velocities appear to be some $40 \%$ lower than upstream velocities observed before as well as after the rapid frontal advance (see Fig. 7). In other words, in a period before the rapid frontal advance, the mass flux in section A-A' was not sufficient to allow all the mass supplied to the glacier farther upstream to pass the section. This imbalance caused by the presence of a, relatively speaking, stagnant ice body near the grounding line must have resulted in a thickening of the glacier upstream of section A-A' in the period prior to the rapid frontal advance.

Furthermore, if the estimated minimum frontal velocity during the frontal advance from 1978 to 1984 of 1.5 $\mathrm{km} / \mathrm{yr}$ is used as starting value for the calculation of a balance velocity distribution, then the calculated balance velocities in the upper ablation area appear to be some $40 \%$ higher than the observed average velocities for the periods 1970-1978 and 1989-1990. The discrepancy is even more pronounced $(72 \%)$ if the more realistic frontal velocity of $2 \mathrm{~km} / \mathrm{yr}$ is used as starting value for the balance-velocity calculation. This means that during the rapid frontal advance, the mass flux through cross-sections in the upper ablation zone of Storstrømmen was far from sufficient to keep up with the combined mass loss by surface ablation and mass flux out of the cross-section located at the 1978-frontal position. Consequently glacier thinning must have taken place in the lower ablation zone during the rapid frontal advance.

The pattern of velocity fluctuations described above, i.e. 'stagnant' ice near the frontal end of the glacier before the rapid frontal advance and flow velocities much greater than balance velocities during the rapid frontal ad- vance, is typical 'surge' behaviour. It shows that the frontal advance was not a normal response to mass balance changes.

\section{Summary and discussion}

During a relatively short period after 1978 , the calving front of Storstrommen advanced $10-12 \mathrm{~km}$ to a position similar to that occupied in 1913. The large frontal advance was first recognised in 1989 by comparing field observations of frontal positions with aerial photographs from 1978. By analysis of LANDSAT images, the time for the advance has been more precisely determined to between 1978 and 1984. During the advance about 50 $\mathrm{km}^{3}$ of ice was transferred from the upper to the lower reaches of Storstrømmen, and $218 \mathrm{~km}^{2}$ of former fjord area was covered by glacier ice. The striking similarity between the 1913 and 1984 frontal positions strongly suggests that the advanced 1913-position of the glacier front was also the result of a rapid advance. If true, this suggests possible periodic frontal fluctuations of Storstrømmen with a period of the order of 70 years.

By comparing observed and estimated surface velocities before, during and after the rapid advance with calculated steady state balance velocities, it has been shown that large velocity fluctuations accompanied the fluctuations of the position of the glacier front. As described above, the pattern of these velocity fluctuations is typical 'surge' behaviour, and shows that the frontal advance was not a normal response to mass balance changes. The relatively long duration (5-6 years) of the active surge phase is longer than typical surging ice masses in the greater part of the World, but agrees well with the duration of the active phase as described for surging glaciers in Svalbard (Dowdeswell et al., 1991).

The two calving fronts, the Bredebræ front and 'Northern Front', show different behaviour after the active surge phase. Only two years after reaching the maximum extent, the region of the glacier behind the Bredebræ front began to disintegrate, releasing a large segment of the front (Fig. 3). The 'Northern Front', by contrast, has not yet started to retreat.

The stability of a floating ice tongue depends on lateral and subglacial bedrock attachment (Mercer, 1961). At the 'Northern Front' a kind of stability of the front seems to have been secured by the Bræøerne which serve as pinning points for the floating tongue. Bredebræ lacks this bedrock contact. This probably explains why the advanced Bredebræ front is less stable than 'Northern Front' as indicated by the following evidence: (1) Intensive calving occurred during the Bredebræ frontal advance. (2) The maximum extent of the advance only lasted from 1984 to 1986 , after which a large segment of 
ice broke off. (3) Some time before 1950, the Bredebræ front had retreated back to the position it subsequently occupied until 1978; it apparently reached a stable balance between ice-flow and iceberg calving. This may be compared to the more gradual retreat of 'Northern Front' in the period after 1950, which lasted until the re-advance of 1978 (Fig. 5).

Along the grounded section of tide water glaciers, instability is likely to occur when backpressure is reduced (Meier \& Post, 1987). If the glacier is grounded below sea level, a slight thinning is likely to considerably reduce basal friction. This, in turn, may cause increased extensional flow, which results in further thinning. Another consequence of the reduced basal friction is that a larger proportion of the driving force due to gravity must be taken up by lateral shear along the sides of the glacier. Thus, shear stresses along the side margins may eventually reach the shear strength of the ice resulting in shear rupture and further increase of the rate of extensional flow. A well developed shear zone along a large part of the eastern margin of Storstrømmen observed in 1989 but not seen on the aerial photographs from 1978 suggests that shear rupture actually occurred along this margin between 1978 and 1989.

As appears from Figure 4, the base of Storstrømmen is located more than $200 \mathrm{~m}$ below sea level over a section extending 30-40 km behind the 1978 grounding line. Thus, the conditions for the instability caused by the feed-back mechanisms described above are certainly present for Storstrømmen.

The glaciological programme on Storstrømmen is continuing. New data collected since 1990 are expected to provide information about present trends of surface elevation and velocity changes and will be used for setting up a dynamic model for Storstrømmen, with the purpose of supporting the above discussion in a quantitative way.

Acknowledgements. Frede Madsen, Kort- og Matrikelstyrelsen (formerly Geodetic Institute), Copenhagen, Denmark is thanked for the loan of a JMR-1 Doppler satellite receiver in 1989 and 1990, and for spending time on instructing us in the use of the instrument. Frede Madsen also kindly lent us two ASHTECH GPS receivers in 1990 which were operated in the field in collaboration with I. Hauge Andersson (formerly Kort- og Matrikelstyrelsen now at the Danish Polar Center, Copenhagen, Denmark) whose help is also very much appreciated. Niels Henriksen and Ib Olsen, GGU, are thanked for their excellent organisation of logistic support in connection with the field work. Special thanks go to Hans Jepsen and Jørgen Neve at GGU's photogrammetric laboratory for their help in preparing the glacier maps and cross-sections of Storstrømmen. The research was supported by the European Programme on Climatology and Natural Hazards under EC Contract EPOC CT90-0015, and by the Commission for Scientific Research in Greenland (Reg. nr. 28829). Carl Egede Bøggild was additionally funded by the Danish Natural Science Research Council.

\section{References}

Braithwaite, R. J. 1984: Calculation of degree-days for glacierclimate research. Z. Gletscherk. Glazialgeol. 20, 1-8.

Bøggild, C. E., Reeh, N. \& Oerter, H. 1993: Ablation reconstruction and mass-balance sensitivity to climate change assessed by modelling on Storstrømmen, North-East Greenland. In Reeh, N. \& Oerter, H. (ed.) Mass balance and related topics of the Greenland ice sheet. Open File Ser. Gronlands geol. Unders. 93/5, 60-63.

Bøggild, C. E., Reeh, N. \& Oerter, H. 1993: Modelling ablation and mass-balance sensitivity to climate change of Storstrømmen, North-East Greenland. Global and Planetary Change $\mathbf{9}$, 79-80.

Dowdeswell, J. A., Hamilton, G. S. \& Hagen, J. O. 1991: The duration of the active phase on surge-type glaciers: contrast between Svalbard and other regions. J. Glaciol. 37(127), 388-400.

Echelmeyer, K., Clarke, T. S. \& Harrison, W. D. 1991: Surficial glaciology of Jakobshavn Isbræ, West Greenland: Part I. Surface morphology. J. Glaciol. 37(127), 368-382.

GGU 1990: Storstrømmen. Internal report, The Geological Survey of Greenland, Copenhagen Denmark. Topographic base map compiled by the Geological Survey of Greenland. Aerial photographs and ground points supplied by Kort- og Matrikelstyrelsen, Danmark (A200/87).

GGU 1992. Storstrømmen (front). Internal report, The Geological Survey of Greenland, Copenhagen Denmark. Topographic base map compiled by the Geological Survey of Greenland. Aerial photographs and ground points supplied by Kort- og Matrikelstyrelsen, Danmark (A200/87).

Hamilton, R. A. et al., 1956: British North Greenland expedition 1952-4: scientific results. Geogr. J. 122, 203-237.

Higgins A. K. 1991: North Greenland glacier velocities and calf ice production. Polarforschung 60(1), 1-23.

Higgins A. K. \& Weidick, A. 1988: The world's northernmost surging glacier? Z. Gletscherk. Glazialgeol. 24 (2), 111123.

Koch J. P. 1913: Gennem den hvide Ørken, 286 pp. København: Nordisk forlag.

Koch J. P. \& Wegener, A. 1911: Die glaziologischen Beobachtungen der Danmark-Expedition. Meddr Gronland 46(1), 77 pp.

Koch J. P. \& Wegener, A. 1930: Wissenschaftliche Ergebnisse der dänischen Expedition nach Dronning Louises Land und quer über das Inlandeis von Nordgrönland 1912-1913 unter Leitung von Hauptmann J. P. Koch. Meddr Gronland 75(1), $676 \mathrm{pp}$.

Meier, M. F. \& Post, A. 1987: Fast tidewater glaciers. J. Geophys. 92(9B). 9051-9057.

Mercer, J. H. 1961: Response of fjord glaciers to changes in firm limit. J. Glaciol. 3(29), 850-858.

Mock S. J. 1966: Fluctuation of the terminus of the Harald Moltke Bræ, Greenland. J. Glaciol. 6(45), 369-373.

Olesen O. \& Reeh, N. 1969: Preliminary report on glacier observations in Nordvestfjord, East Greenland. Rapp. Gronlands geol. Unders. 21, 41-53.

Overgaard S. 1984: Radio echo sounding in Greenland. Data 
Catalog 1979. Electromagnetic Institute, Technical University of Denmark.

Reeh, N. 1991: Parameterization of melt rate and surface temperature on the Greenland ice sheet. Polarforschung 59(3), 1989, 113-128.

Reeh N., Oerter, H. \& Neve, J. K. 1991: Supra-glacial lakes on Storstrømmen Glacier, Northeast Greenland, and their relation to ice dynamics. Abstract in Deutsche Gesellschaft für Polarforschung. 16. Internationale Polartagung. Göttingen April 1991.

Reeh N., Bøggild, C. E. \& Oerter, H. 1993: On the dynamics of
Storstrømmen, an outlet glacier from the North-East Greenland Ice sheet. In Reeh, N. \& Oerter, H. (ed.) Mass balance and related topics of the Greenland ice sheet. Open File Ser. Gronlands geol. Unders. 93/5, 54-59.

Rutishauser H. 1971: Observations on a surging glacier in East Greenland. J. Glaciol. 10, 227-236.

Weidick, A. 1984: Location of two glacier surges in West Greenland. Rapp. Gronlands geol. Unders. 120, 100-104.

Weidick, A. 1988: Surging glaciers in Greenland - a status. Rapp. Gronlands geol. Unders. 140, 106-110. 